\title{
Latex allergy and its clinical features among healthcare workers at Mankweng Hospital, Limpopo Province, South Africa
}

S M Risenga, ${ }^{1}$ BSc, MB ChB, DCH, Dip Allerg (SA), MMed (Paed), FAAAI, Cert Pulmonol (SA) Paed; G P Shivambu, ${ }^{1} \mathrm{MB}$ ChB; M P Rakgole, ${ }^{1} \mathrm{MB}$ ChB; M L Makwela, ${ }^{1} \mathrm{MB} \mathrm{ChB}, \mathrm{DCH}(\mathrm{SA})$;

S Ntuli, ${ }^{2}$ BSc, BSc Hons, MSc; T A P Malatji, ${ }^{2}$ MB ChB, M Fam Med, Dip HIV Man;

N J Maligavhada, ${ }^{1}$ BSc, MB ChB, DCH, FCPaed (SA);

R J Green, ${ }^{3}$ MB BCh, DTM\&H, MMed (Paed), DCH, Dip Allerg, FCPaed (SA), FAAAAI, FCCP, PhD

\begin{abstract}
${ }^{1}$ Department of Pulmonology and Allergy, Polokwane/Mankweng Complex and University of Limpopo, Limpopo, South Africa ${ }^{2}$ Department of Public Health Medicine, Polokwane/Mankweng Complex and University of Limpopo, Limpopo, South Africa ${ }^{3}$ Department of Paediatrics and Child Health, University of Pretoria and Steve Biko Academic Hospital, Pretoria, South Africa
\end{abstract}

Corresponding author: S Risenga (sam.risenga@gmail.com)

\begin{abstract}
Background and objectives. Latex allergy, caused by sensitisation in atopic individuals, is a common occupational disease among healthcare workers who use latex gloves. It may be present in non-atopic individuals as well. The main objective of this study was to document the prevalence and disease spectrum of latex allergy at Mankweng Hospital, Limpopo Province, South Africa. The secondary objective was to determine clinical presentation of the disease.

Methods. A cross-sectional descriptive study, with an analytical component, was conducted among healthcare workers who worked in high-risk areas for latex sensitisation. ImmunoCAP testing was performed and followed by a skin-prick test (SPT) in those who tested negative to the blood test.

Results. Two hundred screening questionnaires were distributed to healthcare workers at the hospital. Of these 158 (79.0\%) were returned, with 59 participants meeting the inclusion criteria (experiencing symptoms due to wearing latex gloves). The mean age of the participants was 39.6 years (standard deviation 9.8 years, range 20 - 60 years). There were more females (98.1\%) than males (1.9\%). Glove-related symptoms were present in 59 subjects $(37.1 \%)$, in 7 (11.9\%) of whom the ImmunoCAP was positive to latex (95\% confidence interval $4.2-22.9 \%)$. Fourteen participants were lost to follow-up before the SPT was performed. Thirty-eight of the participants with negative ImmunoCAP tests underwent SPT. Positive SPTs were reported in 5 of these 38 workers (13.2\%), indicating that the ImmunoCAP test missed $11.1 \%$ (5/45) of latex-allergic individuals. The prevalence of latex allergy in this study was $8.3 \%(12 / 144)$. A denominator of 144 was used, as there is a possibility that some of the 14 individuals lost to follow-up could have tested positive to latex sensitisation by SPT. The symptoms experienced by latex-sensitised workers were rhinitis (100.0\%), asthma (50.0\%), dermatitis (25.0\%), severe anaphylaxis (8.3\%), abdominal pain (8.3\%) and angio-oedema (8.3\%).

Conclusion. Our findings reveal that latex allergy is a problem at our hospital. The prevalence of $8.3 \%$ is comparable to findings in other
\end{abstract} South African centres. We recommend a latex-free protocol for high-risk areas and healthcare workers.

S Afr Med J 2013;103(6):390-394. DOI:10.7196/SAMJ.6011

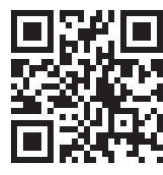

Gloves made from natural rubber latex (NRL) have been in use since the 19th century as a means of protecting patients and healthcare workers from contracting infectious diseases. ${ }^{[1]}$ The use of NRL gloves has increased because of the emergence of the human immunodeficiency virus (HIV) in the late 1980s. ${ }^{[1]}$ These NRL gloves were produced with an excess of residual proteins and powder. ${ }^{[1]}$

Healthcare workers (HCWs) are susceptible to sensitisation and subsequent development of latex allergy because of frequent exposure to NRL gloves and powder. ${ }^{[2]}$ In addition, the prevalence in certain groups, such as people who underwent multiple operations involving exposure to NRL-containing materials at an early age, and those with spina bifida, urological abnormalities and short-bowel syndrome, has been reported to be up to $60 \%$ in earlier studies ${ }^{[3]}$ However, this high prevalence is falling as a result of a reduction in exposure to latex. ${ }^{[3]}$

Latex allergy is more prevalnet in atopic than non-atopicindividuals. ${ }^{[3]}$ There is also cross-reactivity with certain foods, including kiwi fruit, bananas, avocados and chestnuts. ${ }^{[3]}$ Such cross-reactivity may occur in more than $50 \%$ of latex-allergic individuals, and is due to specific crossreacting allergens such as profilins. ${ }^{[4]}$ Notably, about $50 \%$ of medical devices contain latex, so care has to be taken to identify them and avoid contact by latex-sensitised and allergic individuals. ${ }^{[1]}$

In highly industrialised countries such as those of Europe and North America, the latex epidemic in HCWs has been partly halted by prevention strategies such as lowering the protein content in gloves ${ }^{[5]}$ recommended by task forces of the European and American allergy associations. ${ }^{[5]}$ New cases of NRL allergy have been significantly reduced, and in certain circumstances have disappeared, in countries and hospitals where health authorities have enforced the use of lowallergen/low-protein and non-powdered protective gloves. ${ }^{[3]}$

The first cases of latex allergy (type I hypersensitivity) were described in 1927 in Germany. ${ }^{[5]}$ The first case in South Africa (SA) was diagnosed in 1993 at Groote Schuur Hospital in Cape Town, in a nursing sister. ${ }^{[6]}$ 
Reactions to NRL gloves can present in three ways:

1. Contact dermatitis on the hands after wearing gloves resulting from mechanical friction and drying due to dry powder particles. This is not an immune-mediated reaction and accounts for the majority of latex-induced skin rashes.

2. Allergic contact dermatitis is a type IV delayed hypersensitivity reaction usually caused by the chemical accelerators (such as carbamates, thiurams and benzothiazoles) used in the manufacture of NRL gloves. This is a cell-mediated immune response that develops 24 - 48 hours after exposure to latex.

3. The type 1 immediate hypersensitivity reaction to latex, an IgEmediated hypersensitivity reaction to latex protein, can result from contact with latex allergens through the skin or mucous membranes. It has not been documented that the powder used in latex gloves is allergenic, but it may carry latex proteins that can lead to an allergic reaction on coming into contact with mucous membranes. Symptoms usually begin within minutes of exposure. This is the most serious type of latex allergy and may be fatal.

This study's main objective was to determine the prevalence of latex allergy at Mankweng Hospital, a 500-bed rural tertiary teaching hospital of the University of Limpopo, Polokwane Campus, Limpopo Province, South Africa. The secondary objective was to determine the disease spectrum of affected staff members exposed to latex gloves.

\section{Material and methods Study population}

A cross-sectional descriptive study was conducted among HCWs (nurses, medical doctors and cleaners) working in high-risk areas of Mankweng Hospital. The great majority of HCWs at highest risk of latex sensitisation are nurses. Ethics clearance was obtained from the Ethics Committee of the University of Limpopo, Polokwane Campus. The participants signed forms indicating their informed consent to participate in the study.

Participants were recruited during March - December 2011 from the intensive care unit, labour ward, gynaecology and postnatal ward, casualty, outpatient department, neonatal intensive care unit, antenatal clinic, operating theatre, central sterilising department, radiology, high care, and the Thuthuzela Rape Clinic. The hospital has a nursing staff complement of 704 and has a policy of keeping nurses in their preferred workstations permanently. All participants had been in their workstation for a year or more. The number of nurses in different stations is shown in Table 1.

\section{Sample size}

We assumed the prevalence of type 1 latex allergy in the study population to be about $10 \%$, with a margin of error of $4 \%$. In order to be $95 \%$ confident we needed to have a total of 200 HCWs in high-risk areas using simple random sampling.

\section{Development and logistics}

We conducted a small-scale pilot study of 10 participants in January 2011 to test our questionnaire. We then started our study by having a discussion on latex allergy in every workstation in order to explain the study and answer questions. Questionnaires and information on latex allergy were given to HCWs who wanted to participate in the study. We collected blood from participants who met the inclusion criteria and later did skin-prick tests (SPTs) in those whose blood tests were negative.

\section{Questionnaire}

A self-administered questionnaire was designed to elicit any allergic symptoms, collecting the following information: $(i)$ demographic data; (ii) symptoms; (iii) family history; (iv) food allergy (avocados, bananas, carrots, pineapples and watermelons); ( $v)$ previous allergy evaluation and therapy; (vi) hospitalisation; and (vii) surgery. The questionnaire was in English, the official language used to record patient information at the hospital. HCWs in different workstations were addressed to explain the study, and questions asked were clarified. They were addressed in English, Sepedi, Tshivenda and Xitsonga, the four common languages spoken at the hospital. For the few participants who could not understand English well, the information was interpreted in their home language by the investigators, who can speak all three African languages. There is evidence that a questionnaire addressing past symptoms of latex allergy can be useful in screening for latex allergy. ${ }^{[7]}$ Questionnaires are particularly useful in the identification of sensitised and asymptomatic patients belonging to high-risk groups and in prevalence studies. ${ }^{[5]}$

Participants were required to score their symptoms after exposure to latex as absent, mild, moderate or severe and to state whether they were

Table 1. Number of healthcare workers and participants per workstation

\begin{tabular}{|c|c|c|c|}
\hline Workstation & $\begin{array}{l}\text { Total population per } \\
\text { workstation, } N\end{array}$ & $\begin{array}{l}\text { Study sample per } \\
\text { workstation, } n\end{array}$ & $\begin{array}{l}\% \text { of study sample per } \\
\text { workstation }\end{array}$ \\
\hline Intensive care unit & 33 & 27 & 81.8 \\
\hline Labour ward + antenatal clinic & 44 & 30 & 68.2 \\
\hline Obstetrics and gynaecology & 50 & 23 & 46.0 \\
\hline Casualty & 24 & 21 & 87.5 \\
\hline Outpatient department & 36 & 18 & 50.0 \\
\hline Postnatal ward & 33 & 15 & 45.5 \\
\hline Neonatal unit (including NICU) & 46 & 9 & 19.6 \\
\hline Central sterilisation and supply department & 14 & 8 & 57.1 \\
\hline Operating theatre & 35 & 3 & 8.6 \\
\hline Radiology & 2 & 1 & 100.0 \\
\hline High care & 6 & 2 & 33.3 \\
\hline Thuthuzela (rape centre) & 4 & 1 & 25.0 \\
\hline Total & 327 & 158 & 48.6 \\
\hline
\end{tabular}


work-related or not. Symptoms were graded as severe if the participant had needed medical attention or admission to hospital.

Inclusion criteria for further study (latex sensitisation and allergy testing) were: (i) confirmed or suspected latex allergy; (ii) severe reaction after exposure to latex; (iii) allergy to food that cross-reacts with latex; (iv) any other symptom with work-related deterioration; (v) 1 or more severe symptoms listed in the questionnaire; (vi) 2 or more moderate symptoms in the questionnaire; and (vii) 4 or more mild symptoms in the questionnaire. Fifty-nine participants met these inclusion criteria for latex sensitisation and allergy testing.

\section{Specific IgE measurements}

The k82 Latex ImmunoCAP system (Phadia, Uppsala, Sweden) was used to determine serum-specific IgE to latex antigens. The latex allergen components documented on this system are Hev b $1, \mathrm{Hev} b$ 2, Hev b 3, Hev b 5 Hev b 6.01, Hev b 6.02, Hev b 7.01, Hev b 7.02 Hev b 8, Hev b 9, Hev b 10 and Hev b 11. The first 7 latex allergens listed above are of medium to high significance, with Hev b 7.01 through Hev b 11 having low significance in HCWs and children with spina bifida. ${ }^{[8]}$ There is cross-reactivity, especially to bananas, avocados and kiwi fruit, with Hev b 6.01 through Hev b 6.03. Hev b 8 to Hev b 11 reveal low cross-reactivity with some fruit and mould allergens. ${ }^{[8]}$ A value of $>0.35 \mathrm{kU} / 1$ was considered positive. Clotted blood was collected and sent to Lancet Laboratory, Polokwane, for testing.

\section{Skin-prick tests}

SPTs were performed on subjects who tested negative to blood tests. We used standardised $1 \mathrm{~mm}$-tipped lancets (ALK-Abello, Madrid, Spain) and latex extracts $(500 \mu \mathrm{g} / \mathrm{ml}$ protein concentrate). Histamine $(10 \mathrm{mg} / \mathrm{ml})$ was used as a positive control and normal saline as a negative control (ALK-Abello). A drop of the extract was placed on the volar area of the forearm and introduced into the epidermis through lancet puncture. The result was examined after 15 minutes and the average diameter of the wheal measured. A positive result was interpreted as an average diameter of $\geq 3 \mathrm{~mm}$ compared with the negative control.

\section{Results}

A total of 158 HCWs (all nurses) returned the questionnaires and therefore participated in the baseline study, giving a participation rate of $79.5 \%$ (158/200). Doctors and cleaners did not return the questionnaires, perhaps because they did not regard themselves as being at risk for latex allergy. Demographic characteristics of the study participants are presented in Table 2 .

The mean age of the study participants was 39.6 years (standard deviation (SD) 9.8 years, range 20 - 60 years). There were more females (98.1\%) than males. Fourteen participants did not continue with the study due to: death (2), proving untraceable (4), and refusal to continue for personal reasons (8). Glove-related symptoms were present in 59 HCWs (37.1\%), of whom 7 (11.9\%) had positive SPTs to latex (95\% confidence interval $4.2-22.9 \%$ ). Latex (K82) titres of the participants who tested positive were, in ascending order, 0.87 $\mathrm{kU} / \mathrm{l}, 1.16 \mathrm{kU} / \mathrm{l}, 2.51 \mathrm{kU} / \mathrm{l}, 3.61 \mathrm{kU} / \mathrm{l}, 7.74 \mathrm{kU} / \mathrm{l}, 14.5 \mathrm{kU} / \mathrm{l}$, and 45 $\mathrm{kU} / \mathrm{l}$. Thirty-eight participants with negative blood tests underwent SPTs, 5 of which were positive, with readings of $3 \mathrm{~mm}, 3 \mathrm{~mm}, 4 \mathrm{~mm}$, $4 \mathrm{~mm}$ and $7 \mathrm{~mm}$.

Positive SPTs were reported in 5 out of 38 workers with negative blood tests (13.2\%), indicating that blood tests missed $11.1 \%$ of latex-allergic individuals (5/45). The prevalence of latex allergy among HCWs was $8.3 \%(12 / 144)$, after adjusting for the 14 subjects lost to follow-up before SPT. The symptoms experienced were rhinitis in 12 (100.0\%), asthma in $6(50.0 \%)$, dermatitis in 3 $(25.0 \%)$, anaphylaxis requiring mechanical ventilation for 2 weeks in $1(8.3 \%)$, urticaria in $1(8.3 \%)$, abdominal pain in $1(8.3 \%)$ and angio-oedema in $1(8.3 \%)$.

The number of latex-sensitised or allergic individual HCWs per workstation was also determined (Table 3 ). The proportion was highest among labour ward staff.

\section{Clinical symptoms in participants who met inclusion criteria for sensitisation testing}

The clinical symptoms of the participants are listed in Table 4. Of note is that 54 participants had more than one symptom. Among those who were positive to either the ImmunoCAP test or the SPT, symptoms were as follows: 5 had 1 symptom, 4 had 2 symptoms and the other 3 had 3 or more symptoms. All the participants who tested positive had rhinitis, and half had asthma. There was no statistically significant difference between the sensitised (latex-positive) and non-

Table 2. Demographic characteristics of the study participants $(N=158)$

\begin{tabular}{cll}
\hline & $\boldsymbol{n}$ & $\%$ \\
\hline Gender & 156 & 98.1 \\
Female & 2 & 1.9 \\
Male & & \\
Age (years) & 7 & 4.4 \\
$20-24$ & 21 & 13.3 \\
$25-29$ & 21 & 13.2 \\
$30-34$ & 29 & 18.2 \\
$35-39$ & 24 & 15.1 \\
$40-44$ & 30 & 18.9 \\
$45-49$ & 26 & 16.4 \\
$\geq 50$ & &
\end{tabular}

\section{Table 3. Prevalence of latex allergy and sensitisation according to workstation}

\begin{tabular}{llll}
\hline & $\begin{array}{l}\text { Participants per } \\
\text { workstation, } \boldsymbol{N}\end{array}$ & $\begin{array}{l}\text { Latex-sensitised } \\
\text { participants, } \boldsymbol{n}\end{array}$ & $\begin{array}{l}\text { Prevalence of latex } \\
\text { sensitisation per } \\
\text { workstation, \% }\end{array}$ \\
\hline Labour ward and antenatal & 30 & 5 & 16.7 \\
Outpatient department & 18 & 3 & 16.6 \\
Intensive care unit & 27 & 2 & 7.4 \\
Obstetrics and gynaecology & 23 & 1 & 4.3 \\
Casualty & 21 & 1 & 4.8
\end{tabular}


Table 4. Clinical signs and symptoms

\begin{tabular}{|c|c|c|c|c|c|}
\hline & \multicolumn{2}{|c|}{$\begin{array}{l}\text { Latex-positive group (sensitised) } \\
\qquad(N=12)\end{array}$} & \multicolumn{2}{|c|}{$\begin{array}{l}\text { Latex-negative group (non-sensitised) } \\
\qquad(N=47)\end{array}$} & \multirow[b]{2}{*}{$p$-value ${ }^{*}$} \\
\hline & $n$ & $\%$ & $n$ & $\%$ & \\
\hline Rhinitis & 12 & 100.0 & 35 & 74.5 & 0.101 \\
\hline Asthma & 6 & 50.0 & 14 & 29.8 & 0.305 \\
\hline Dermatitis & 1 & 8.3 & 22 & 46.8 & 0.019 \\
\hline Anaphylaxis needing ventilation & 1 & 8.3 & 0 & 0 & 0.203 \\
\hline Abdominal pains & 1 & 8.3 & 5 & 10.6 & 1.000 \\
\hline Urticaria & 1 & 8.3 & 3 & 6.4 & 1.000 \\
\hline Angio-oedema & 1 & 8.3 & 2 & 4.2 & 0.501 \\
\hline
\end{tabular}

sensitised (latex-negative) groups with regard to rhinitis, asthma, anaphylaxis requiring ventilation, abdominal pain, urticaria and angio-oedema $(p>0.05)$. A statistically significant association was observed with regard to dermatitis in terms of latex exposure in the two groups $(p<0.05)$.

\section{Discussion}

The participation rate was adequate, with $79 \%$ answering the questionnaires. The sample was not obtained by random selection, however, but depended on participants returning questionnaires. As a result, generalisability to the hospital may not be possible.

Among the 59 participants who met the inclusion criteria (symptoms due to using latex gloves), 12/45 (26.7\%) tested positive for latex sensitisation by ImmunoCAP or SPT. The findings are comparable to those of studies conducted at Dr George Mukhari Hospital (Pretoria) $(22 \%)^{[9]}$ and Groote Schuur Hospital (Cape Town) (25.3\%). ${ }^{[6]}$

Our latex allergy prevalence of $8.3 \%$ is higher than the $4.2 \%$ at the Dr George Mukhari Hospital, which is our sister hospital. ${ }^{\left[{ }^{[]}\right.}$This difference can partly be explained by the fact that in the latter study only the ImmunoCAP test was performed, with no SPT follow-up. We calculated our prevalence with only the ImmunoCAP without an SPT result in the participants with negative blood tests and found a prevalence of $4.9 \%$ (7/144), similar to that of the Dr George Mukhari study.

The prevalence of latex allergy at other SA teaching hospitals and institutions has been reported as: Groote Schuur Hospital (Cape Town) 9.2\%, Red Cross War Memorial Children's Hospital (Cape Town) 5\%, Tygerberg Hospital (Parow, Cape Town) 20.8\% and the South African Institute of Medical Research, now the National Health Laboratory Service (Johannesburg), $10.5 \% \cdot{ }^{[10]}$ Our prevalence of $8.3 \%$ is comparable to most of these, with only Tygerberg Hospital demonstrating a higher prevalence of $20.8 \%$. The actual prevalence of latex sensitisation may be higher than these figures suggest, because some studies show that 25\% of SPT-positive patients may be asymptomatic. ${ }^{[10]}$

Rates of latex sensitisation and allergic reactions have increased in HCWs exposed to NRL since the 1980s, with prevalences of $6.9-17 \%$ reported. ${ }^{[11,12]}$ A study on primary prevention of NRL allergy in Germany by Allmers et al. has confirmed a positive correlation between the use of powdered NRL gloves and suspected occupational latex allergy. ${ }^{[13]}$ There is recent evidence that rates of NRL allergy have fallen significantly as a result of latex-free environment strategies and use of low-allergen, powder-free gloves in some industrialised countries. ${ }^{[3]}$ Termination of exposure to NRL products is an accepted means of secondary prevention in latexsensitised individuals. ${ }^{[13]}$
The commonest presenting symptoms in both latex-positive and -negative participants who met the inclusion criteria were nasal ( $100.0 \%$ and $74.5 \%$, respectively), followed by asthma in latexpositive $(50.0 \%)$ and contact dermatitis in latex-negative subjects $(46.8 \%)$. Other symptom profiles did not reveal any significant differences between latex-positive and -negative participants. There was no statistically significant difference in symptoms between the latex-sensitised and non-sensitised participants, except in those who presented with dermatitis. This can be explained by the fact that the k82 ImmunoCAP does not test some Hev b allergens such as Hev b 6.03, Hev b 12 and Hev b 13. ${ }^{[7]}$ SPTs may be negative even in people who are sensitised or allergic to latex, as sensitivity has been shown to be $93-96 \% \cdot{ }^{[14]}$

\section{Shortcomings of the study}

Greater participation, especially by doctors, would have improved the power and generalisability of the study. Several participants only had blood testing performed without follow-up SPTs, which could have influenced the prevalence, as some might have tested positive by SPT.

\section{Recommendations}

NRL allergy has been shown to be an important cause of occupational disease. It is important to increase awareness of the sensitising and disease-causing effect of latex gloves in HCWs. Powdered gloves may cause serious latex allergy problems because the latex proteins adhere to the powder, become airborne and are subsequently inhaled. ${ }^{[13]}$ This can cause sensitisation in atopic individuals.

Powdered latex gloves can be a hazard not only to the wearer but also to other people in the workstation. The importance of creating latex-free workplaces cannot be over-emphasised, as evidenced by one of our participants who developed anaphylaxis requiring mechanical ventilation. In an ideal situation latex-free gloves should be used, especially in high-exposure areas. This is not feasible in most settings, however, because of the high cost of these gloves. ${ }^{[15]}$ It is therefore recommended that powder-free, low-allergen gloves be used as a preventive measure because of their ability to decrease sensitisation. ${ }^{[10]}$ Individuals who are sensitised to latex should avoid direct contact with latex gloves but can work at the station with other workers provided the latter are using powder-free gloves.

Once an individual is sensitised it is difficult to prevent the emergence of symptoms, especially systemic reactions on contact with latex. ${ }^{[13]}$ Everyone with proven latex allergy should wear a Medic Alert bracelet or band to help HCWs avoid using latex-containing products 
such as urinary catheters, endotracheal tubes, oxygen facemasks and laryngeal airways when caring for them.

\section{Conclusion}

The prevalence of latex allergy in HCWs at Mankweng Hospital is significant, and represents a serious occupational disease. It is important to strive for a latex-free working environment for HCWs, especially atopic workers. Risk risk of latex allergy could be minimised by decreasing extractable proteins in latex products. This may reduce the risk of litigation against the hospital and Department of Health.

\section{References}

1. Mota ANB, Turrini RNT. Perioperative latex hypersensitivity reactions: An integrative review. Rev Lat Am Enfermagem 2012;20(2):411-420. [http://dx.doi.org/10.1590/S0104-11692012000200026]

2. Galindo MJ, Quirce S, Olmos LG. Latex allergy in primary care providers. J Investig Allergol Clin Immunol 2011;21(6):459-465.

3. Palosuo T, Antoniadou I, Gottrup F, Phillips P. Latex medical gloves: Time for reappraisal. Int Arch Allergy Immunol 2011;156:234-246. [http://dx.doi.org/10.1159/000323892]

4. Leung DY, Sampson HA, Geha R, Szefler SJ. Pediatric Allergy: Principles and Practice. 2nd ed. Edinburgh: Elsevier Saunders, 2010.
5. Cabanes N, Ilgea JM, de La Hoz B. Latex allergy: Position paper. J Investig Allergol Clin Immunol h2012;22(5):313-330.

6. Potter PC, Crombie I, Kosheva O, et al Latex allergy at Groote Schuur Hospital - prevalence, clinical features and outcome. S Afr Med J 2001;9:760-765.

7. Buss ZS, Kupek E, Frode TS. Screening for latex sensitization by questionnaire: Diagnostic performance in health care workers. J Investig Allergol Clin Immunol 2008;18(1):12-16.

8. Steinman $\mathrm{H}$, Ruden S. ImmunoCAP, native and recombinant allergen components. Allergy - Which Allergen? Phadia AB, 2010:115-132.

9. Ismail NA, Hoosen AA, Mehtar S. Latex allergy in health care workers: Prevalence and knowledge at a tertiary teaching hospital in a developing country. International Journal of Infection Control 2010;6(1):16. [http://dx.doi.org/10.3396/ijic.v6i1.004.10]

10. Potter PC. Latex allergy in Southern Africa. Allergy and Clinical Immunology International 2002;14(1):10-13. [http://dx.doi.org/10.1027/0838-1925.14.1.10]

11. Braithwaite N, Motala C, Toerten A. Latex allergy - the Red Cross Children's Hospital experience. S Afr Med J 2001;91(9):750-751.

12. Allmers H, Schmengler J, Malte S. Decreasing incidence of occupational contact urticaria caused by natural rubber latex allergy in German health care workers. J Allergy Clin Immunol 2004;114(2):347351. [http://dx.doi.org/10.106/jaci.2004.05.054]

13. Allmers $\mathrm{H}$, Schmengler J, Skudlik C. Primary prevention of natural rubber latex allergy in the German health care system through education and intervention. I Allergy Clin Immunol 2002:110(2):318-323. [http://dx.doi.org/10.1067/mai.2002.126461]

14. Hamilton RG, Peterson EL, Ownby DR. Clinical and laboratory-based methods in the diagnosis of natural rubber latex allergy. J Allergy Clin Immunol 2002;110:S47-S56. [http://dx.doi.org/10.106/ mai.2002.125334]

15. Filon FL, Radman G. Latex allergy: A follow up study of 1040 healthcare workers. Occup Environ Med 2006;63:121-125. [http://dx.doi.org/10.1136/oem.2003.011460]

Accepted 18 February 2013. 